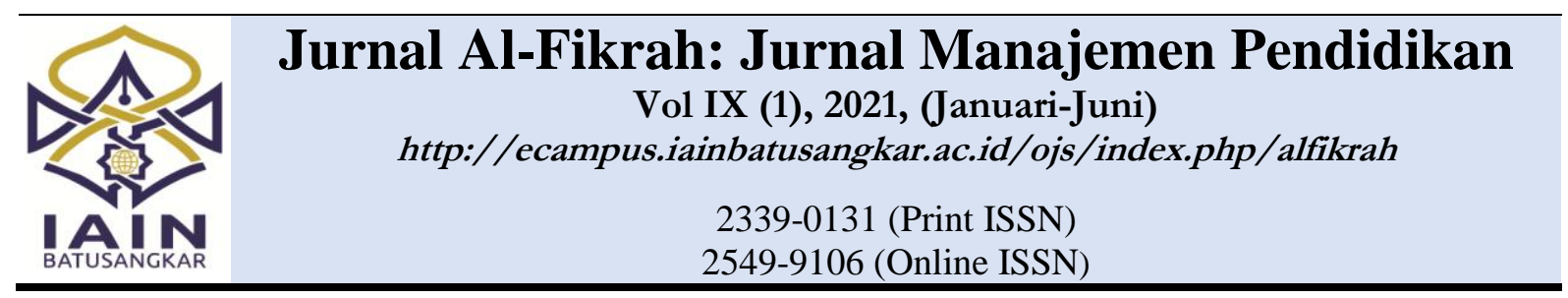

\title{
English Language Teaching Management Strategies to Improve Students' Higher Order Thinking Skills
}

\author{
Strategi Manajemen Pengajaran Bahasa Inggris untuk Meningkatkan \\ Keterampilan Berpikir Tingkat Tinggi Siswa
}

Received: 14-01-2021; Revised: 08-06-2021; Accepted: 17-06-2021

\author{
Mega Selvi Maharani ${ }^{*}$ \\ Study Program of Educational Evaluation and Research, Graduate School, Universitas Negeri Yogyakarta, \\ Yogyakarta 55221, Indonesia \\ E-mail: megaselvi6@gmail.com \\ *) Corresponding Author
}

\begin{abstract}
1200
Abstrak: This study aimed to assess, explore and describe management strategies to improve students' HOTS in English practice. Research was focused on planning, implementing, and evaluating in improving English learning. This study used descriptive qualitative research, the subjects were owners of the event organizer, students, and volunteer. Data collection techniques used observation, interviews and documentation. The results showed that planning was written in the guidebook and arranged based on need analysis that has been done. Implementation was tuning in planning project, HOTS implementation activities in junior high schools were more concerned on students' confidence level in English communication and the application of HOTS in the real world. Meanwhile, the application of HOTS in Senior high school was more emphasis on critical thinking and problem-solving. The evaluation was divided into two parts, the evaluation of participants was to measure the achievement level of learning and evaluation of activities was measuring for the improvement of the event.
\end{abstract}

Keywords: Higher order thinking skills; learning management system; motivation

\begin{abstract}
Abstrak: Penelitian ini bertujuan untuk menilai, mengeksplorasi dan mendeskripsikan strategi manajemen untuk meningkatkan HOTS siswa dalam praktik bahasa Inggris. Penelitian difokuskan pada perencanaan, pelaksanaan, dan evaluasi dalam meningkatkan pembelajaran bahasa Inggris. Penelitian ini menggunakan jenis penelitian deskriptif kualitatif, subjek, penelitian adalah pemilik. Yayasan Dabuni, mahasiswa, dan relawan. Teknik pengumpulan data menggunakan observasi, wawancara dan dokumentasi. Hasil penelitian menunjukkan babwa perencanaan dituangkan dalam buku pedoman dan disusun berdasarkan analisis kebutuban yang telah dilakukan. Pelaksanaannya sesuai dengan perencanaan proyek, kegiatan pelaksanaan HOTS di sekolah menengah pertama lebih memperhatikan tingkat kepercayaan siswa dalam komunikasi bahasa Inggris dan penerapan HOTS di dunia nyata. Sedangkan penerapan HOTS di SMA lebih menekankan pada berpikir kritis dan pemecaban masalah. Evaluasi dibagi menjadi dua bagian, evaluasi peserta untuk. mengukur tingkat pencapaian pembelajaran dan evaluasi kegiatan untuk, peningkatan acara.
\end{abstract}

Kata kunci: Keterampilan berpikir tingkat tinggi; Manajemen sistem pembelajaran; motivasi. 
INTRODUCTION

The application of Higher Order Thinking Skill in Indonesia has

been used since latest curriculum was establish as movement of learning in the 21st century. HOTS was used in Indonesia on the basis of perfecting the curriculum to confront internal challenges such national standard education demands as improving human resources, external challenges related to globalization in order to improve mindset, strengthen curriculum governance and strengthen materials (Kemendikbud, 2014). However, there were many problems faced to improve learning using HOTS, especially in learning English. The problems that usually arose in the application of HOTS are the less of teacher preparation and knowledge, besides of students' problem in controlling of their motivation in learning (Ginting \& Kuswandono, 2020). These problems could be faced by giving more knowledge to the teacher and giving teaching program to the student to provide their motivation. One of program that provided the activities to increase of HOTS learning is Dahuni Foundation annual event.

The aimed of the event explicitly refers to enhancing the student's competence in English. It was appropriate to the issues faced by Indonesian as a country that uses English only in learning process or English as a foreign language, thus placed Indonesia on listed in the category of low English Proficiency (Dahuri, 2019). It could be said that there should be an enhancement in quality of English learning method. Therefore, the solution may be offered by a notion of how to improve the output in the process of learning and teaching English. The output of English teaching-learning is not only seen from the scores obtained on the assessment of each student improvement (Durrani et al., 2020), but also the results of practical exams verbal practices (Murpy 2013). Assessment of students should not only be on the test scores they accived, but also on the practice of English that could be applied by students both in the school scope or communities.

The practice of English meets a wider range of problems such as the lack of confidence and motivation (Megawati, 2016; Souriyavongs, 2013). Students' lack of selfconfidence are evidence of the frequency of English speaking practices that are rarely applied in learning process, forward psychology affective factors of student are rarely stimulated when student speaks English (Afisa, P. 2015). This case is influenced by lack of motivation (Fitrianto et al., 2016).

While motivation is also influenced interested in learning and the learning environment (Asvio, 2015). Based on the problem above, there were several solutions that can solve student motivation and confidences by giving positive impact towards increasing personal satisfaction and stimulate the absorption of knowledge and skills (Assanova \& \& Gagova, 2019). To minimize the issues described above, DF provides the annual event to increase the level of students' English practiced by applying the attractive ways, the appropriate methods, and also they are directly guided by the native speakers in the field.

The program is to increase students' interested in English, then these activities are suitable to the epoch. Activities with good preparation and design have been highlighted in Central Java (Ashadi, 2019), the uniqueness of the event should be used as a good example of activities that supported learning as extracurricular outside of school. Based on fact above the researcher was interested to see how the management of these event because this program got a very good appreciation from both formal and informal institutions. This research was focused on seeing the management of these activities such as planning, implementation, and evaluation process. Previous studies that have examined the same thing were research on (Sandela, 2019) about Implementation Of Learning Management in Elementary School. This research focuses on planning, processes and outcomes in teaching learning. This management emphasized more on learning in formal schools, that cased was distinguishing of this this research. The second previous studies was conducted by (Dilah et al.,) about Educator Recruitment Management, the 
component of the management were same as this research such planning, processes and evaluation, but this research was done by observational research while previous research was done by theoretical study.

The research question in of the current study was how were the planning, implementation, and evaluation of management strategies to improve students' higher order thinking skills which were carried out by Dahuni Foundation. Qualitative research was carried out to provide detailed information to the reader about how the management and the stages passed through DF activities, to give literature to the reader in holding of program in order to improve student learning practices and to provide a new strategic for teachers when they teach.

\section{Theoretical Support}

The Government of Indonesia applies many new policies, one of that is the application of Higher Order Thinking Skills. Based on Ministry of Education and Culture Regulation No. 59 of 2014 states that curriculum 2013 is developed by rationalizing internal and external learning challenges, improving mindset, strengthening curriculum governance, and strengthening materials, the program which updated is utilization of HOTS in learning process (Kemendikbud,2018). Other objectives of the application of HOTS are the fulfillment of cognitive aspects in $21 \mathrm{st}$ century learning (Arafah, Arsyad, \& Helmi, 2013), increasing creativity and learning motivation (Nguyễn \& Nguyễn, 2017) rearranging and expanding knowledge in new ways (Frausel et al., 2020) helping students generate ideas and solve their problems in daily life (Heong et al., 2012). Thus, its concluded that HOTS is an important factor in improving the quality of education in Indonesia.

HOTS is very appropriate to applied in learning English, especially in speaking skills, these skills not only lead students to practice expressing more opinions but also giving an idea that must be conveyed. This is parallel to the purpose of applying HOTS on languages learning which is used to express their ideas while speaking (Murphy, Bianchi, McCullagh,
\& Kerr, 2013) (Heong et al., 2012) (Higgins, 2017). However, there are challenges that must be faced by the government in the application of HOTS such as adjusting the curriculum with reality, difficulty of applying HOTS in large classes, lack of teacher teaching skills, difficulty of implementing coherent planning, difficulty of implementing metacognitive, infusion approach requires complex knowledge (Vijayaratnam, 2012). These challenges can be faced by application of HOTS in right way, to support that improvement is needed collaboration among government, schools, teachers, students, and academics.

In the implementation of small organizations, the main responsibility for teaching-learning process is taken by a teacher, who can control all the conditions that run in the classroom. The teacher must have a strategy that is suitable and can be used in the learning. Ensuring the application of different methods of learning must be used (Armstrong et al., 2020), There are many suitable strategies and methods used in the application of HOTS like experimental method, role play, question and answer, demonstration, conversing (Arafah et al., 2013) direct instruction or teacher centre presentation, classroom environmental (Nguyễn \& Nguyễn, 2017). Furthermore, the suitable learning model used in the application of HOTS can be Cooperative Learning (Kemendikbud,2016) Discovery / Inquiry, Project-based Learning / PPA, (Ariyana, Pudjiastuti, Bestary, \& Zamromi, 2018), Problem-based Learning / PBL (Riadi \& Retnawati, 2014). Learning process is the crucial aspect that should control by teacher, the teacher must be able to control and make interested class by using of good method for implementing of HOTS. In the other hand, there are important components in education such us parents, educational institutions/teachers, and the community (Nurasa, 2013). To improve the quality of learning, the teachers/educators must always be implemented, then good curriculum designed should prepared as well (Liza, 2013). Furthermore, the main thing that must be done is to independently evaluate all 
activities by paying attention to the quality of good management and adjusting available time (Putra et al., 2018).

Developing the education quality of a management system it is very important to achieve the ideals and expectations of a program (Arnanda \& Usman, 2020) (Mukhid, 2007). Management is a key to the success of an agency that runs effectively and efficiently (Arnanda \& Usman, 2020), the requirement which having is good and right principles (Putra et al., 2018). Management means commitment to carry out activities to achieve goals (Becker et al., 2017). Management is other way to improve the successful of learning process, management can be done by teacher and other department which can help to control the learning progress, in this case who can is headmaster, administrator, or learning developer.

Managerial events include organizational planning, implementation, and control or evaluation activities (Cetin and Tortop 2018) (Putra, Ayuningtiyas, Wafira, \& Akbar, 2018) which are carried out according to target and accuracy (Arnanda \& Usman, 2020). Planning is setting goals and determining actions to achieve goals (Fadlallh, 2015) (Lussier \& Kimball, 2009) organizing is the process of coordinating tasks and resources to achieve goals, implementation is implement the programs that have been designed on the planning (Putra et al., 2018), and evaluation is activities to review the program to consider and maintain the value of a program (Ananda \& Rafida, 2017). In the process managerial school or event, people who include the program have the responsibilities to improve the learning progress. Therefore, good management is good issues to discuss.

\section{METHOD}

This study used qualitative research that was used in investigations to obtain information by analyzing individuals or phenomena in the real environment. The researcher functions as a direct observer. The subjects of this study were the owners of the Dahuni Foundation, volunteers, teachers and students. The event held on 17-20 June 2019 in Purbalingga, although the implementation has been carried out for long time, a similar program has never been carried out in Indonesia till the nowadays. Purposive sampling was a technique used to determine the subject of this research, collecting data using observation, interviews, and documentation. Observations as participants have been used, researchers participate as volunteers who teach and assist throughout the program.

Observations were carried out to see the process of implementing activities, monitoring and evaluation carried out during the process of implementation the program. Observation using observational checklists. Interviews have guidelines that aim to limit the discussion in one context that was needed, interviews using interviews face to face in order to obtain results that truly support research. The purpose of the interview was to find out an explanation of the planning, implementation, and evaluation that has been carried out, in addition to the interview also given to students to provide opinions related to the activities that have been carried out. Researcher called the student by phone to confirm the information that got from the volunteer. Documentation has a rainy guideline to see everything needs in the management of the program itself, such as planning, modules, and a list of managerial. Data was getting from the owner of the program. Data Analysis used refers to the theory (Miles \& Huberman, 2014) namely data condensation, data exposure, conclusion drawing and verification. Data condensation was used to collect and separate the used and useless data. After separate the data, made the conclusion in each of part of the question, confirm interview the data from volunteer and student, matched the data result among interview, observation and documentation. Drawing the conclusion to answer the research question.

\section{RESULT AND DISCUSSION}

Education the new era is growing rapidly making all sectors must move quickly in achieving the goals, for getting good 
achievements sectors in education should have the best quality of management which shape up by the time (Putra et al., 2018). Dealing this event could accelerate and follow the latest learning styles in the 21 st century, this event has a lot of impact if there was no support of other parties and similar activities that support the acceleration of the development of education in Indonesia, that why it is very important to know management of the activities which has been successfully carried out. Management is a process to achieve goals through a series of planning, organizing, controlling and evaluating human resource activities (Arnanda \& Usman, 2020) monitoring, and assessing (Cetin \& Tortop, 2018). In the implementing an event the main activities applicable are formulation or planning activities, implementation, and evaluation (Kurniawati, 2017), the three stages are sufficient to represent the activities that have taken place.

Each of year DF hold on the annual event to improve English skill in Indonesia, the main objective of DF Annual event is Introducing the DF to local schools, improving students' English skills, sharing knowledge and experience with local English teachers on alternative ways to teach English. One of the events that has been held this year was an event called Blusukan the theme used was: Bringing English to the life which means a surprise visiting. Blusukan was held on 17-20 June 2019 in Purbalingga, was one province in jawa that close to the central of education (Yogyakarta). This activity was carried out with the assistance of local and international volunteers. Managing was taking the long preparation before the implementation, the agenda was divided to some part of activities such planning, organizing, implementation, and controlling/evaluation.

The general purpose described by DF above was a solution of existing problems, the problem can be solved by knowing the many problems that actually occur and the solutions that must be faced (Paglis, 2013). First, improving students 'English skills by helping students' problems in practicing English in Indonesia, this cased was coming up to solve the problem of students who lack of application and practice in using English so as to make students less confident the problem of students who lack of application and practice in using English so making students less confident (Souriyavongs, 2013; Megawati, 2016). Second, sharing knowledge and experience among English teachers is solving teacher problem, the teacher must have a good approach and method for students, in order to achieve learning objectives (Cortazzi \& Jin, 1996).

\section{Planning of Blusukan Event}

Planning was the main thing that must exist in carrying out an activity, both small or large activities. Planning activities were carried out to decide on the goals and the things that support those objectives. Data was taken from the results of interviews, and documentation, interviews conducted with the owner and his staff, and also volunteers who help the running of these activities. Planning was carried out several months before the event, with the following sequence: October and November 2018 outline activities, December and January compile detailed activity programs including the creation of modules, February volunteer recruitment, March collaboration with schools, April and May communication and carrying out administrative affairs of the MOU between schools, the Sponsor and Dahuni Foundation. In the planning stage, it was carried out by the owner of the foundation, staff, the team from the school, and the volunteers. References used in the preparation of activities that are based on the needs analysis or research carried out with the following specifications: students' initial ability, fun activities, collaborative, learning in the world of students, learning by using English. Arikunto (2009); Becker et al., (2017) State that the management is the effort of a group's collaborative in achieving certain goals. In a plan it has components of vision, mission, goals, objective action strategies (Gilbert, et al., 2011). This is exactly what the DF manager has carried out with the general and specific objectives of this event. The objectives that 
have been explained above are focus on improving students' English.

Based on analysis of document and short interview, there were three main of objective, three purpose of the event, and some of goals in each of activities that hold on. The place chosen by the Dahuni Foundation and also the teacher of Purbalingga, the event held in school and at tourist sites, the aim was to increase tourism in Purbalingga with the presence of foreign tourists there, in addition to that activities were also carried out in crowded places so that there was a lot of learning gained by participants from daily life in that places. The implementation of these objectives was parallel to the need of the era of the $21 \mathrm{st}$ century to achieve good educational goals in the application of HOTS, to achieve good achievements in education required good quality management in accordance with the times (Putra et al., 2018). The event was holding in SMPN 3 Purbalingga on first day and in Alun-Alun Purbalingga on the second day, in Desa Wisata Serang karangrejo on the third and the fourth day. The time was chosen to follow the academic calendar in holiday so it did not annoy the students' activities at school, the time was specified for each activity so that activities could be carried out according to the previous plan. The timing applied in this program is in accordance to needs and rules of the learning processing system which select the educational calendar and arranging the learning schedule (Ningsih, 2020).

The executer was manager and volunteers, the manager was two owners of DF and volunteers were selected by the owner of the foundation based on the background of the instructor, through interview or making a video in the form of an introduction and the purpose of participating in the activity, the distribution of voluntary responsibilities depends on experience, by providing responsibility for each activity. Participants who took part in this activity were 100 participants of junior high students on the first second days and 100 participants of senior high school on the next two days. Collaboration/MOU: carried out by the
Dahuni Foundation and the Association of English Teachers who agreed on the existence of these activities, the distribution of tasks, as well as providing opinions in initial planning. This was according the aim of HOTS in Indonesia Direktur Jendral Pendidikan Islam (2018) which was to link the knowledge possessed to the realities of around, then learning through the real world and working in small groups to energize language classes which can connect theory with practice to develop students' high skills (Vijayaratnam, 2012). The third goal was to introduce culture and build friendships from different backgrounds, it related to the HOTS function of embracing different of gender, ethnic, thought, learning styles and intelligence (Higgins, 2017). The first objective was to use a method that was associated with daily activities, this was the development of the second goal, the application of HOTS for students in learning English.

Modules was guideline that used English Language, those was given to the students and Volunteers by clearly describing the activities that must be carried out. The Module was including the name of the activities, day/date, specific time, and leader of the activities, goal in each of session, and procedure of the activities which divided into briefing, warming up, main activity, closing. Modules were compiled based on research obtained and based on existing standards in the subject of learning in Texas A\&M with adaptation to the needs of the Purbalingga region, these activities are oriented towards 21 st Century learning namely critical thinking, creativity, communication and collaboration using HOTS. Methods were designed based on experience and knowledge, research through educational concepts, emphasizing pleasant practices, giving suitability to the tools or media used. Methods that used was fitting to the HOTS learning but it was not explained in the module for specifically. Based on the research, the method used is Practice (Role Play), Games, Discussion, Listening to the music, Report presentation of Blusukan. Media was the tools that used in the activities, so many media that used. Each of the activities 
DF has approximately 2 kind of media, the example of media that used is Ball, Dice, Doll, Music, Madding, PPT. Methods that are adapted to HOTS learning needs, Errors in the selection of strategies can result in imperfections in achieving goals, or even failure to achieve their goals (Kasman, 2012).

Organizing was the arrangement of the organization, in this case the organization of Dahuni Foundation, the task division was determined by forming many small groups, by giving different responsibilities to each volunteers. Responsibility was given in accordance with the capabilities possessed by volunteers. The following is the organization of the implementation plan. a) The owner and co-owner (two people) with responsibility are planning all activities from start to finish, dividing tasks for participants and volunteers, time keepers, coordinating with the school, overseeing how the activities were carried out, providing input and documenting activities. b) Local and international Volunteers (20 people), Metees and scholarship recipients (5 people) Supporting committees in the regions are tasked with licensing, covering and preparing participants, while volunteers carry out activities according to the initial plan, interact with students, lead activities, deliver material, carry out activities by providing practical examples with students. Each of session was leading by three people, then two people were divided into small group and interact to the student. Volunteers from Indonesia who were included in the event are teachers and students who have strong basic English and foreign volunteers who have competence in teaching. This selection was a demand for effective learning, English teachers cannot teach well because of the frequent use of mother tongue when learning a foreign language (Dembo, 2004). The right thing to be the solution is learning with native English speakers (Cortazzi \& Jin, 1996) learning with native speakers brings students into the naturalness of the language itself. Problems that would be possible will arise that students do not understand what was natively said, by dividing volunteers in pairs using one Indonesian volunteer and one foreign volunteer, it was hoped that the problem could be overcome and solve.

\section{Implementation of The Event}

Implementation could be interpreted as mobilizing one's ability in the activities that carried out. The implementation of Blusukan activities organized by the Dahuni Foundation was a practical based learning activity provided by national and international volunteers. The implementation was divided into two main activities for junior and senior high schools where each level is given 2 days in the implementation of its activities. According to the results of observations and interviews given to volunteers and also students stated that the activities had been done in accordance with the procedures and plans that had been previously stated in the Module. Each activity was divided into several parts with one and a half hours each side. Following are the data on the activities carried out on June 17-20 2019. Implementation is the main key of an event which accordance to the existing design. Based on Suryosubroto (1990) the implementation is divided into three part of activities as the opening, main activities and the final activities (Arafah et al., 2013). The opening activity intended here is an introduction activity that is implemented by Dahuni Fauodation when implementing games activities, this was used to stimulate students to enthusiasm in carrying out further activities. Then, the main activity was the Blusukan and Critical thinking activities which are carried out as the initial purpose of DF to hold this activity. The final activity was the evaluation or assessment which was used to assess the improvement in student learning outcomes during the activity. Implementation which has been undertaken needs analysis previously starts directly without any pre-tests, but in the design of objectives in the activity has been carried out needs analysis before. Implementation of activities that have been adapted to the plan with high discipline so that the generalization can be said that the implementation is in accordance with the plan.

Implementation of activities tailored to existing plans in the module which have been 
adjusted to students' the learning needs. On the first day the activities put more emphasis on games and introductions, to the introduction of the Busulkan project itself. Welcoming Session was a time of introduction between volunteers and students to get closer Warm Up Games and My Picture Session was a game to give students interest in the activities they do. Lunch and Learn Session is an activity that is carried out during lunch, it was used to stimulate students to learn English from the things closest to them. Peeling The Onion Session was a learning activity to stimulate students to be able to develop ideas and ideas that appear when conducting a research Blusukan Orientation and Assignment activities that provide the foundation of actual learning, which would be used in practice in the real world. Give examples in interviews and set appropriate goals. The problem encountered on the first day was timeliness because some agendas require quite a long time.

The implementation in second day the Blusukan Project was carried out for interviewing local residents, interspersed with a number of previous activities, the final activity was closed with a presentation of the Blusukan activity that had been carried out. Breaking Bread Session, Blusukan Report Preparation and Blusukan Presentation was a series of Blusukan event or the main activities in the application of HOTS. This activity was in the form of directly knowing the community's activities by examining the activities carried out by the surrounding community and their daily lives, after getting information about the local community, students are given time to discuss about the findings that they got and make conclusions from the problems obtained in the community, students were also trained to provide advice and solutions to the problem. In the final activity the students summarize, analyze, and create solution in these problems and present their results in front of the other groups. In one group there were only 9-10 students, the final assessment is carried out by assessing the results of student analysis and presentations. The Encouragement and Jar
Project Session was a self-introduction activity by international volunteers, it was carried out to give an interest to students to be more active in learning. This activity was accompanied by evaluation activities for the participants and for the annual activity.

The third day was held for high school students where students have many activities for self-development that were tailored to methods that emphasize critical thinking. Welcoming Session. Warm Up Games, The X Factor Session, Lunch and Learn Session is a series of games that sharpen the brain and create a high enough stimulus at the Senior High School level, this activity multiplies their ideas and knowledge as far as they learn and experience. Critical Thinking, Session Through Humans Of New York (HONY) was a core activity that emphasizes high-minded thought patterns, not only creating ideas but also developing ideas directly without giving notes first. The ideas were developed in accordance with the instructions given by the instructor, this learning is carried out in a circle and open discussions. With each group of 10-12 people. Posts Lyp-Sync Battle, Orientation and Assignment, Lyp-Sync Battle Practice Session of learning activities that are rarely implemented in schools due to lack of learning time, the function of this listening activity was to give their sensitivity to the actual English language, or the use of English in the real world. In the evening students had activities in the form of Bond fire. These activities were aimed at motivating students to learn, providing suggestions for learning and continuing school for students. Last day in this activity students were given the opportunity to display what has been learned on the previous day. After listening to and understanding the meaning of the song they got, each of them made a show to create a work of dancing. The activity was a closing activity as well as to assess student learning outcomes.

The activities contradicted with the aim of the application which it was to enhance student's confidence in learning process. By practicing the methods, there were international and local volunteers as well as native speakers applied the novel and 
supportive methods for learning practice. Native speakers used relatively new and supportive methods for practice in learning (Farrell, 2019). HOTS is accurately applied using the methods of games play, role play, discussions and presentations that the application was very suitable to be applied in learning English. Such methods of role play, question and answer, demonstration, conversation, and the experiment are applied in HOTS (Arafah et al., 2013)formal and informal interviews, discussion groups, active dial-up between teacher and students, and through daily notes (Grainger, 2005). Implementation that is applied through small groups in these event can be useful in absorbing material, increasing student collaboration and creativity, developing skills in research and decision making (Webber, O’Neill, \& Dossinger, 2020). The strategies used in developing idea, thought patterns, forcing students to find solutions and create conclusions that can be applied in the real life (Arafah et al., 2013). This activity was in conform in the focus in the development of HOTS namely 4Cs critical thinking, communication, collaboration, and creativity ( Arafah et al., 2013; Ariyana et al., 2018; Kemenag, 2018; Sofyan, 2019). The strategy applied by DF employed problem-based learning where students are given the activities to analyze the issue emerging in the community and recommend an appropriate solution to the problem. According to Riadi \& Retnawati (2014) problem based learning can improve students' problem solving skills.

The whole of the implementation of Blusukan event almost matched to the main planning. Even though, some problem occurred such the first planning students of high school would stay with volunteers. It aimed to provide students to be closer to international volunteers so that practical English was used more often. However, in its implementation the plan could not be implemented due to lack of communication and arrangements as well as preparation. The implementation generally was not same as exactly the planning. this was related to the discipline of both volunteers, students, and teachers. The volunteers have been given prior directions to deal the things that will happen so its already prepared beforehand. In carrying out activities there were some difficulties encountered, although structured management was very important for a very long term but institutional views must be considered (Nanang, 2004). The problems were also faced by DF that there are some considerations that were not possible to be carried out but it was not reduce the essence of the event.

In the implementation of DF event students was divided into small group based on students' ability that can possible to stimulate the absorption of knowledge. Selection and replacement of groups that could increase motivation then students can be flexible in situations and different study groups (Asanova \& Gaganova, 2019) in this case, it was appropriate at the high school level. For the junior level the thing that must be considered was the problem of lack of confidence and the application of HOTS that used newly which could make students find it difficult to produce ideas due to lack of awareness of their capacity (Heong et al., 2012). Each implementation of an activity was usually encounters its own problems however the implementers must have a good design that would be achieved to determine of the goal. The implementation of short activities like this should have a short break for preparation so that the implementation was not left behind, it was to fill in the worst possibilities that will occur.

\section{Evaluating of The Event}

Implementation did not escape from evaluation and controlling, oversight in this activity has been carried out well by the two leaders of the DF, the supervisor's task was to provide an explanation of the method, time, and all matters covering implementation, provide guidance and problem solver for volunteers, provide question and answer, provide daily planning, coordinate with surrounding communities and conduct evaluations. Volunteers supervise participants in each group who have been given responsibility. On each side the Dauny 
Foundation leaders went around to supervise directly and remind them of the remaining time or time that was still running. While the teacher's job was to supervise students until the student gets the group that has been determined. In general the supervision has been carried out by various parties as well. evaluating is to determine the achievement of objectives (Putra et al., 2018) controlling has been carried out well by the two owners of the DF. The evaluation related to the process provide information that could be used as a consideration to determine the worth and merit of the goals achieved, design, implementation and impact to help making decisions, giving responsibility and improve understanding of what was going on (Ananda \& Rafida, 2017: 3). Evaluation was carried out by all parties that involved, the evaluation emphasizes more on informal discussions and input from students. The evaluation process was done every day after the event was over, it included evaluation of achievement and evaluation of failures that occur on the day concerned.

Based on observation in evaluation, most of the activities hold on was successful. Evaluation was carried out in a circular position and open discussion, both volunteers or managers were free to give their opinions. The evaluation included discussion of the previous agenda, obstacles encountered, the satisfactory time, opinions and student input, the event running out and the quality of the material and presenters. The problems faced during the evaluation were the limited time and fatigue of managers and volunteers which making less of the focus and less in depth of discussion. The validation of students emphasized more on oral and verbal where students were directly charged for learning achievement and the discussion that has taken place. At the end the students were given the task to present and display the learning outcomes they have got. For the final evaluation carried out to determine the next policy with advice given by volunteers and students.

Based in writer analysis, the implementation of each activities were almost entirely successful, the method used in the evaluation of activities was the evaluation of discussion models. The evaluation activities were divided into two parts: firstly, evaluation was conducted for students to assess the improvement in their performance and the application of what they have been learning, to see the development of knowledge and skills by understanding the skills possessed by students and treated them with new knowledge (Harvey, Spurr, Sidebotham, \& Fenwick, 2020). However, the accession of HOTS is strongly based on motivation and previous experience (Roets \& Maritz, 2017) the assessment must not be subjective because the implementation of the activity was only carried out within two days. Secondly, an evaluation was carried out to assess the ongoing activities done by all implementers, this aims to ensure that performance does not deviate the objectives (Fadlallh, 2015). The evaluation stage has been good implemented in this program so that this program could be valued as internal measurement.

\section{CONCLUSION RECOMMENDATION}

\section{Conclusion}

The Dahuni foundation's event in improving students' HOTS in English learning was divided into three specific stages such the planning implementation, and evaluation. Planning that has been carried out to improve students' skills is to provide goals according to their needs who basically focus on the goals of applying HOTS with social activities. Determining time and appropriate location, implementers of the activities, the modules, method have been planned as well. Implementation of the event in increasing the students' HOTS was divided into two stages, the implementation carried out for junior high school students and senior high school students at different times and locations. Controlling to determine the achievement of the objective has been carried out by the two owners of the foundation. Evaluation was carried out by dividing the two parts, evaluation for participants and evaluation for voluntary activities. Evaluation for participants 
was carried out as an assessment of the improvement of student learning in this activities, this assessment was in the form of a direct assessment which is giving the results of the discussion, presenting or showing students task. Assessments for the event were done in a routine agenda that was hold out after the end of activity.

\section{RECOMMENDATION}

This kind of event is good to apply in the countries such as Indonesia, for the application of English using HOTS with the support by foreign instructors which allows teachers and students to use new methods and strategies but what is unfortunate in this activity is these activities are only focused on student activities whilst the teacher still needs help in improving the skills and methods they have. Writer hopes that other activities that will be occur are activities that can improve the skills and knowledge of the teacher, this aims to create a teacher training to develop skills, strategies and subsequent application of HOTS. Moreover, HOTS elements in English language learning can be improved by supporting as early as possible children speaking (Frausel et al., 2020) which can be interpreted that the application of HOTS not only starts at the high school level but also at the basic learning level, this is to stimulate HOTS learning to be applied at a higher level. Children can express their ideas more when speaking than writing (Murphy et al., 2013) making foundation learning using HOTS that starts from primary school should begin from learning to speak and express ideas that children have, this can be realized in short activities such as those conducted by DF. The emphasis in the application of HOTS in basic education is not to develop analysis, evaluation, problems solving (Ariyana et al., 2018; Ulva, 2019) but rather to stimulate how children can express their ideas and deal the daily problems in the world of children. Furthermore, to continue the deepening of this study, in-depth research is need to seek the input of the program.

\section{REFERENCE}

Ananda, R. \&, \& Rafida, T. (2017). Pengantar Evaluasi Program Pendidikan. Yogyakarta: Perdana Publishing.

Arafah, K., Arsyad, M., \& Helmi. (2013). Penguatan MGMP dalam membuat soal fisika higher order thinking skills ( HOTS ), 448-450.

Ariyana, Y., Pudjiastuti, A., Bestary, R., \& Zamromi. (2018). Buku Pegangan Keterampilan Berpikir Tingkat Tinggi Berbasi Zonasi. Direktorat Jendral Guru dan Tenaga Kependidikan.

Armstrong, L., Harding, F., Critchley, J., McNarry, A. F., Myatra, S. N., Cooper, R., \& Baker, P. A. (2020). An international survey of airway management education in 61 countriest. British Journal of Anaesthesia, (April), 1-7. https://doi.org/10.1016/j.bja.2020.04.0 51

Arnanda, S., \& Usman, N. (2020). The Management Programs of Aceh Tengah Educational Board Chairman in Improving the Quality of Elementary Education. Jurnal Pendidikan Progresif, 10(1), 83-90. https://doi.org/10.23960/jpp.v10.i1

Asanova, B., \& Gaganova, P. (2019). Motivation in the education process. KNOWLEDGE - International Journalledge, 34, 435-438. Diambil dari https://ikm.mk/ojs/index.php/KIJ/arti cle/view/2136

Assanova, B., \& \& Gagova, P. (2019). Motivation in The Education Procces. KNOWLEDGE - International Journal, $34.2,435-438$.

Asvio, N. (2015). Dengan Minat Belajar Mahasiswa Semester Iii Program Studi Diploma Iii Kebidanan. al-fikrah: Jurnal Manajemen Pendidikan, III(1), 95-108.

Dilah, S. D. ., Ramadani, K., \& Abubakar. (2020). Managemen pemberdayaan tenaga administrasi di MTS AlFathimiyah Telukjambe Timur Karawang. al-fikrah: Jurnal Manajemen Pendidikan, V111(2), 127-138.

Direktur Jendral Pendidikan Islam. (2018). Petunjuk Teknis Pengembangan Pembelajaran 
pada Madrasah. Direktur Jendral Pendidikan Islam (Vol. Nomor 5163). https://doi.org/10.29333/aje.2019.423a

Fadlallh, A. wahid. (2015). The Effect of applying managerial skills in the field of management (An application on Sudanese universities in Khartoum). The International Journal of Business \& Management, 3(10), 245-252. Diambil dari www.theijbm.com

Frausel, R. R., Silvey, C., Freeman, C., Dowling, N., Richland, L. E., Levine, S. C., ... Goldin-Meadow, S. (2020). The origins of higher-order thinking lie in children's spontaneous talk across the pre-school years. Cognition, 200(August 2019), 104274. https://doi.org/10.1016/j.cognition.202 0.104274

Ginting, A. A., \& Kuswandono, P. (2020). Challenges Faced by English Teachers: Implementation of Higher Order Thinking Skills (HOTS) in Designing Assignments in East Indonesia. Pedagogy: Journal of English Language Teaching, 8(1), 13.

https://doi.org/10.32332/pedagogy.v8i 1.1688

Harvey, S., Spurr, P., Sidebotham, M., \& Fenwick, J. (2020). Describing and evaluating a foundational education/training program preparing nurses, midwives and other helping professionals as supervisors of clinical supervision using the Role Development Model. Nurse Education in Practice, 42(April 2018), 102671. https://doi.org/10.1016/j.nepr.2019.10 2671

Heong, Y. M., Yunos, J. M., Othman, W., Hassan, R., Kiong, T. T., \& Mohamad, M. M. (2012). The Needs Analysis of Learning Higher Order Thinking Skills for Generating Ideas. Procedia - Social and Behavioral Sciences, 59, 197-203. https://doi.org/10.1016/j.sbspro.2012.0 9.265

Higgins, S. (2017). Managing Higher-Order Thinking Skills. Managing Academic Libraries, 29-40. https://doi.org/10.1016/b978-1-84334621-0.00004-2

Kurniawati, E. (2017). Manajemen strategik lembaga pendidikan islam dalam meningkatkan mutu pendidikan. Jurnal At-Taqaddum, 9(3), 113-132.

Liza, M. (2013). Pelaksanaan Manajemen Berbasis Sekolah: Analisis Deskriptif Tsanawiyah Negeri Pasir Lawas Kabupaten Tanah Datar. al-fikerab: Jurnal Manajemen Pendidikan, 1(2), 174-181.

Murphy, C., Bianchi, L., McCullagh, J., \& Kerr, K. (2013). Scaling up higher order thinking skills and personal capabilities in primary science: Theory-into-policyinto-practice. Thinking Skills and Creativity, 10, 173-188. https://doi.org/10.1016/j.tsc.2013.06.0 05

Nguyễn, T. M. T., \& Nguyễn, T. T. L. (2017). Influence of explicit higher-order thinking skills instruction on students' learning of linguistics. Thinking Skills and Creativity, 26, 113-127. https://doi.org/10.1016/j.tsc.2017.10.0 04

Nurasa. (2013). Manajemen dan Lingkungan Pendidikan Islam. al-fikerab: Jurnal Manajemen Pendidikan, 1(2), 101.

Paglis, L. L. (2013). A Review of Managerial Skills Training in the Classroom. Journal of Management Education, 37(4), 472-498. https://doi.org/10.1177/105256291243 6516

Putra, R., Ayuningtiyas, D., Wafira, I., \& Akbar, R. (2018). Strategies for improving the quality of education in the twenty-first century: Riview of the education system in fatih bilingual school aceh. the Roles of Parents in Shaping Children's Characters (ICECED), 153-163.

Riadi, A., \& Retnawati, H. (2014). Pengembangan Perangkat Pembelajaran untuk Meningkatkan HOTS pada Kompetensi Bangun Ruang Sisi Datar. Pythagoras: Jurnal pendidikan Matematika, 9(2), 126-135. https://doi.org/10.21831/pg.v9i2.9074

Roets, L., \& Maritz, J. (2017). Facilitating the development of higher-order thinking 
skills (HOTS) of novice nursing postgraduates in Africa. Nurse Education Today, 49 , $51-56$ https://doi.org/10.1016/j.nedt.2016.11. 005

Sandela, M. (2019). Manajemen Rekrutmen Tenaga Pendidik Di Sdit Sa'Adiah Kecamatan Kubung Kabupaten Solok. al-fikrah: Jurnal Manajemen Pendidikan, 7(2), 155.

Sofyan, F. A. (2019). Implementasi Hots Pada Kurikulum 2013. Inventa, 3(1), 1-9. https://doi.org/10.36456/inventa.3.1.a1 803

Ulva, fatiyah R. (2019). Higher Order Thinking Skills ( Hots ) Dalam Pembelajaran Bahasa Inggris Sd / MI di
Era Revolusi Industri 4.0. Elementary, 7(2), 323-336.

Vijayaratnam, P. (2012). Developing Higher Order Thinking Skills and Team Commitment via Group Problem Solving: A Bridge to the Real World. Procedia - Social and Behavioral Sciences, 66, 53-63.

https://doi.org/10.1016/j.sbspro.2012.1 1.247

Webber, S. S., O’Neill, R. M., \& Dossinger, K. (2020). The empowering leadership project. Journal of Management Education, 44(3), 342-361. https://doi.org/10.1177/105256291988 4717 